\title{
Customer Perceptions of Loyalty Programs in an Emerging Market Context
}

\author{
Mlenga G. Jere \\ Graduate School of Business, University of Cape Town, Private Bag X3, Rondebosch 7701, South Africa \\ Email: mlenga.jere@gsb.uct.ac.za \\ Charlene Posthumus
}

Graduate School of Business, University of Cape Town

Private Bag X3, Rondebosch 7701, South Africa

Doi:10.5901/mjss.2014.v5n23p278

\begin{abstract}
Difficult economic conditions place pressure on organisations to attract new customers and retain existing ones. One strategy employed to realise this goal is the use of loyalty programs. This paper sought to determine the drivers of customer participation and non-participation in loyalty programs and to determine customer perceptions of loyalty programs. Based on a sample of 181 respondents, the findings show that the main drivers of customer participation in loyalty programs include quality and price while the main reasons for non-participation include lack of offers of membership and the perception that the benefits of participation are not worth the effort. Customer perceptions of loyalty programs were found to be aligned with previous findings in the literature and focussed on rewarding frequent shoppers and ensuring repeat patronage. The study findings were mainly consistent with the literature.
\end{abstract}

Keywords: customer loyalty, loyalty programs, customer relationship management, customer perceptions

\section{Introduction}

With increasing economic uncertainty consumers practice more mindfulness regarding their spending regimes. This in turn has prompted organisations to focus on customer relationship management issues such as customer retention by maximising marketing instruments such as customer loyalty and reward programs (Mägi 2003; Meyer-Waarden 2008). The subject of customer loyalty therefore continues to arouse noticeable interest among both academics and practitioners (Jensen 2011). Though all firms are equally affected, they manage the effects of difficult economic times in different ways (Srinivasan, Rangaswamy \& Lilien 2005). Some firms choose to establish an advantage over their competitors by investing and gaining market share. An example of such investments is the introduction of loyalty programs. Research affirms that market share can become impregnable to competition due to truly loyal customers (Corstjens \& Lal 2000; Ailawadi 2001). However, the mismanagement of customer loyalty can also negatively influence the company's bottomline and compromise profitability (Kumar \& Shah 2004). Loyalty programs can therefore be strategic tools which aid in building a brand, but the programs' overall impact needs to be understood in its entirety (Taylor \& Neslin 2005).

Firms from a wide array of sectors make use of various methods to entice customers to concentrate the majority their spending with them instead of their direct competitors. Not only do these firms make an effort to attract new customers, they also experiment with ways and means of retaining existing customers (Bolton, Kannan \& Bramlett 2000). The implementation of loyalty programs brings about rewards such as cash rebates or redeemable gifts; methods whereby customers are rewarded or incentivised for their loyalty towards the firm or brand (Keh \& Lee 2006). But the establishment of loyalty programs and the capital or profitability requirements are not the only concerns that organisations face (Uncles, Dowling \& Hammond 2003). Questions of program viability and a lack of customer understanding can pose a risk to the program's success and in effect lead to deteriorating margins. Sands and Ferarro (2010) suggest that organisations need to achieve a new level of customer intimacy and can do so by mining available data in order to direct programs to specific customer segments and thus foster customer acquisition, retention and growth strategies.

The purpose of this article is thus to determine how loyalty programs are perceived by customers as well as the factors that influence customer participation in such programs. The specific objectives are a) to determine what the drivers of participation in loyalty programs, b) to determine customer perceptions of loyalty programs is with regards to purpose, and b) to determine the reasons for non-participation. 


\section{Customer Relationship Management and Loyalty Programs}

Customer relationship management (CRM) is a business strategy that is focussed on creating, sustaining and growing long-term relationships with customers (Solanki 2011). Though a means to increasing revenue and profit, it is also a strategy which focuses the organisation towards fulfilling the customers' needs. These needs can be established and be fulfilled with the incorporation of a customer database into the workings of the organisation which allows access to past purchase details as well as other important customer segmentation information (Perreault, Cannon \& McCarthy 2010). Customer loyalty to the organisation or its brand forms a key part of CRM. The employment of such loyalty programs in turn provides valuable customer data needed to run successful CRM initiatives (Liu 2007). The traditional transactional objective of marketing is therefore shifting to a more relationship focused objective with the adoption of CRM practices.

Barnard (2010: 3) views loyalty programs as "structured marketing efforts that are designed to enhance brand loyalty by cultivating an on-going relationship between a marketer and its customers." Oliver (1999) defines consumer loyalty as a deeply held commitment to rebuy or repatronise a preferred product or service consistently. This loyalty can occur at four different levels namely; cognitive, affective, conative and behavioural (Liu 2007). According to Pepe et al. (2011), attitudinal loyalty covers the affective and cognitive aspects and indicates the tendency to demonstrate certain behaviours. In order to achieve "true" loyalty, both attitudinal and behavioural loyalty must be promoted. There is debate around reasons why organisations adopt loyalty programs in part because there is no generally accepted definition for this term (Dick \& Basu 1994). But according to Uncles et al. (2003), loyalty is an attitude that leads to a relationship; is expressed in terms of behaviour; and moderates buying due to the individual's specific characteristics, circumstances and purchase situation. The reasons why organisations may choose to adopt a loyalty program include retaining customers and limiting their movement to competitors (Leenheer, van Heerde, Bijmolt \& Smidts 2007; Uncles, Dowling \& Hammond 2003; Liu, Guo \& Lee 2011; Wallace, Giese \& Johnson 2004), increasing customer loyalty (Demoulin \& Zidda 2009; Meyer-Waarden 2008; Mägi 2003), collecting data regarding consumer shopping behaviour (Kumar \& Shah 2004; Mägi 2003; Rowley 2005; Uncles et al. 2003; Liu 2007; Sands \& Ferarro 2010; Schoenbachler, Gordon, Foley \& Spellman 1997), increasing sales (Uncles et al. 2003; Mägi 2003; Demoulin \& Zidda 2009; Meyer-Waarden 2008), and enhancing commitment (Rowley 2005).

Gruen (1994) and Yi and Yeon (2003) contend that the reasons for participating in loyalty programs are not only economic or emotional benefit, but also prestige or recognition, and the exclusive treatment that accompanies them. Similarly, Liu (2007) states that the psychological feeling of appreciation and personal recognition is not all that customers want. Other psychological benefits include a sense of involvement or partaking in something greater than the purchase (Dowling \& Uncles, 1997), or the ability to indulge in luxuries which would not be justifiable without these rewards (Kivetz and Simonson 2002). Hence the form or type of reward on offer has the ability to create or destroy value for the customer and subsequently either increase or decrease the switching costs from an organisation (Kim, Shi \& Srinivasan 2001).

Customer loyalty can be conceptualised as the customer's attitudinal and behavioural inclination towards one organisation over its competitors (Wallace et al. 2004). But some researchers claim that loyalty programs, specifically those in the grocery sector, are ineffective despite their pervasiveness (Meyer-Waarden \& Benavent 2009). A possible explanation for this is the occurrence of competing firms presenting the same rewards which results in competitive parity; thus minimising differentiation and repeat purchases from a firm (Uncles et al. 2003). Demoulin and Zidda (2009) argue that one of the most significant determinants of loyalty program adoption is not loyalty but commitment towards the organisation. Commitment is thus seen as the main driver responsible for repatronisation and bringing about customer loyalty (Prasad \& Aryasri 2008). Commitment itself entails involvement, identification and loyalty (Rowley 2005).

Consumers in the current economy have low switching costs and thus move freely between brands for reasons such as price and convenience. These low switching costs create a challenge in CRM as customers do not commit to a single brand or retailer. The introduction of loyalty programs as part of the CRM strategy is one means to alleviating the lack of customer commitment and increasing the switching costs (Beerli, Martin \& Quintana 2002; Kim, Shi \& Srinivasan 2001; Wendlandt \& Schrader 2007). Loyalty programs are said to increase the customer's perception of switching costs and ultimately foster customer retention (Bendapudi \& Berry 1997; Wirtz, Matilla \& Lwin 2007). For example, one such switching cost as opined by Taylor and Neslin (2005) is the foregone opportunity to accumulate sales points that contribute to rewards. As members of loyalty programs are rewarded for repeated patronage, they are in effect unconsciously bound to supporting a specific brand or retailer (Sharp \& Sharp 1997).

Although the benefits to having a loyalty program appear to outweigh the negatives; there are various barriers to entry which should be considered. These barriers include (Barnard 2010; Dowling \& Uncles 1997; Rowley 2005; Wendlandt \& Schrader 2007):

- Implementation is expensive: IT operating systems are expensive and a program can take several years 
before it begins making money;

- Signing up partners: Should partners be involved; it is necessary to sign up with those that will add value to your program;

- Strong membership base: Without enough active members the program will not make money. Further, members need to be enticed to use their cards when shopping instead of just signing;

- Late mover disadvantage: The industry is competitive and established programs may be hard to beat; and

- Unique offers: It is becoming increasingly difficult to present the customer with a proposition which is unique and encourages buy-in.

Customer loyalty can thus be driven by either behavioural (repeat purchases) or attitudinal (personal preference) measures (Jacoby \& Chestnut, 1987 as cited by Jensen, 2011). Schoenbachler et al. (2004) note that loyalty does not end with the customer buying the brand, this customer also tends to refuse switching thus increasing spend on the brand or with the retailer they loyal to. For example, Knox and Denison (1999) found that loyal shoppers spend up to four times more than customers who switch-buy. Customer loyalty increases the market share of the preferred brand as consumers repeatedly purchase the brand or from the retailer with which the loyalty lies (Chaudhuri \& Holbrook 2001). In addition to this, loyal customers also tend to make use of other services that the business to which they are loyal might present (Anisimova 2007). But contrary to the foregoing, Sharp and Sharp (1997) as well as Leenheer et al. (2007) contend that loyalty programs show little evidence of behavioural change in consumers. This is similar to Rothschild and Gaidis' (1981) view that loyalty programs only seem to create short-term behavioural changes which do not bring about attitudinal or commitment changes. These negative findings on loyalty programs can be attributed to the polygamous nature of consumers (Dowling \& Uncles 1997; Yi \& Yeon 2003; Gee, Coates \& Nicholson 2008) and the competitive nature of organisations (Ghodeswar 2008; Baltas \& Argouslidis 2007; Dowling \& Uncles 1997).

\section{Method}

Survey data was gathered by making use of the survey host Survey Monkey. The initial sample consisted of 430 individuals whose contact details were available on one of the researcher's database. To facilitate snowballing, the initial sample members were encouraged to distribute the questionnaire to their contacts as well. Working on the base sample of 430 individuals, 191 completed the questionnaire in full resulting in a response rate of $44 \%$. Out of the 191, a total of 181 individual responses were deemed usable. The data was analysed by using percentage splits and frequencies of response.

\section{Results}

\subsection{Sample profile}

The sample was made up of $103(56.9 \%)$ female respondents and 78 (43.1\%) male respondents. The majority of the respondents were in the $30-39$ years old group (38.7\%) as shown Table 1.

Table 1: Age category response count and percentage

\begin{tabular}{|c|c|c|}
\hline & Response Count & Response $\%$ \\
\hline $21-29$ & 52 & $28.7 \%$ \\
\hline $30-39$ & 70 & $38.7 \%$ \\
\hline $40-49$ & 27 & $14.9 \%$ \\
\hline $50-59$ & 26 & $14.4 \%$ \\
\hline 60 or older & 6 & $3.3 \%$ \\
\hline Total & 181 & $100 \%$ \\
\hline
\end{tabular}

Just over three quarters (75.1\%) of the respondents had a post-Grade 12 (post-high school) level of education, indicating that the survey attracted mainly well-educated individuals (Table 2). 
Table 2: Level of Education category response count and percentage

\begin{tabular}{|c|c|c|}
\hline & Response Count & Response \% \\
\hline Grade 12 or less & 45 & $24.9 \%$ \\
\hline Diploma/Certificate & 40 & $22.1 \%$ \\
\hline 3 Year Degree & 30 & $16.6 \%$ \\
\hline Post Graduate & 66 & $36.5 \%$ \\
\hline Total & 181 & $100 \%$ \\
\hline
\end{tabular}

Out of the 181 respondents, 135 (74.6\%) indicated that they were members of at least one loyalty program while rest (i.e., 46) were none members. The proportion of loyalty program members that had multiple memberships was $82.2 \%$ with $17.8 \%$ indicating that they had five or more memberships (Table 3). The majority of these memberships were held in the grocery (34.6\%) and banking (25.3\%) sectors as indicated in Table 4.

Table 3: Number of memberships per individual

\begin{tabular}{|c|c|c|}
\hline Number of Memberships & Response Count & Response \% \\
\hline 1 & 24 & $17.8 \%$ \\
\hline 2 & 37 & $27.4 \%$ \\
\hline 3 & 28 & $20.7 \%$ \\
\hline 4 & 22 & $16.3 \%$ \\
\hline $5-10$ & 24 & $17.8 \%$ \\
\hline Total & 135 & $100 \%$ \\
\hline
\end{tabular}

Table 4: Business Sectors within which memberships are held

\begin{tabular}{|c|c|c|}
\hline & Response Count & Response \% \\
\hline Clothing & 42 & $15.6 \%$ \\
\hline Groceries & 93 & $34.6 \%$ \\
\hline Entertainment & 29 & $10.8 \%$ \\
\hline Travel & 37 & $13.8 \%$ \\
\hline Banking & 68 & $25.3 \%$ \\
\hline Total & $269^{*}$ & $100 \%$ \\
\hline
\end{tabular}

*The response count is greater than 135 because respondents were able to select more than one answer.

\subsection{Reasons for non-membership}

When non-member respondents were asked to indicate their reason for non-membership, the main reasons cited for nonmembership was that they had not been offered any membership (43.5\%) and that they did not find the benefits worth the effort (26.1\%) (Table 5).

Table 5: Reasons for non-membership

\begin{tabular}{|c|c|c|}
\hline & Response Count & Response \% \\
\hline You find it irritating & 9 & $19.6 \%$ \\
\hline You already have too many cards & 4 & $8.7 \%$ \\
\hline You have not been offered any memberships & 20 & $43.5 \%$ \\
\hline You do not find the benefits worth the effort & 12 & $26.1 \%$ \\
\hline Other (please specify) & 1 & $2.2 \%$ \\
\hline Total & 46 & $100 \%$ \\
\hline
\end{tabular}

\subsection{Drivers of participation in loyalty programs}

The $74.6 \%$ of respondents who indicated that they were members of loyalty programs were asked to answer a number of questions in order to gain a better understanding of their behaviour and reasons behind accepting membership. Their 
main reasons for participation were quality, price and service as shown in Table 6.

Table 6: Factors promoting loyalty towards a company or brand

\begin{tabular}{|c|c|c|}
\hline & Response Count & Response \% \\
\hline Price & 88 & $33.0 \%$ \\
\hline Quality & 92 & $34.5 \%$ \\
\hline Service & 75 & $28.1 \%$ \\
\hline Popularity & 12 & $4.5 \%$ \\
\hline Total & $267^{*}$ & $100 \%$ \\
\hline
\end{tabular}

*The response count is greater than 135 because respondents were able to select more than one answer.

\subsection{Customer perceptions regarding purpose of loyalty programs}

Respondents who were members of loyalty programs were also asked to indicate what they perceived the purpose of these programs to be. The majority of respondents regarded the purpose of loyalty programs to be "to reward frequent shoppers" (44.7\%) followed by "to ensure that customers return to the store" (Table 7). None of the respondents indicated that they did not understand the purpose of such programs. Respondents who answered "Other" gave the purpose of loyalty programs as to collect consumer data and analyse behaviours and patterns.

Table 7: Purpose of reward/loyalty programs

\begin{tabular}{|l|c|c|}
\hline & Response Count & Response $\%$ \\
\hline To reward frequent shoppers & 55 & $44.7 \%$ \\
\hline To keep customers from shopping at competing stores & 27 & $22.0 \%$ \\
\hline To ensure that customers return to the store & 37 & $30.1 \%$ \\
\hline I do not understand what the purpose of a loyalty/reward program is & 0 & $0.0 \%$ \\
\hline Other (please specify) & 4 & $3.3 \%$ \\
\hline Total & 123 & $100 \%$ \\
\hline
\end{tabular}

\section{Discussion and Conclusion}

The findings indicate that more females (103) than males (78) responded on the questionnaire. The marginal difference in acceptance between the two genders can also be attributed to the marginally higher degree of brand loyalty that is apparent in the female population when compared to their male counterparts (Beneke, 2010). Although all the different age groupings above 20 were represented, membership was especially prevalent in the $21-49$ years range. This is unlike some previous studies that show that the biggest increase in memberships is in the 18-25 years old consumer group (Radder \& Huang 2008). Previous studies also show that older individuals are more polygamous in part because they have more disposable time and thus the option to frequent more stores (Mägi, 2003). The proportion of respondents with memberships also increased with the level of education.

In order to better understand the reasons behind non-participation, the respondents who indicated that they were not members of loyalty programs were asked to indicate why they were not members. Nearly half of the respondents (43.5\%) stated that their non-membership was due to the fact that they had not been offered memberships. In a time where loyalty programs are being introduced at a high rate, it is difficult to understand why the non-member respondents have not been offered memberships. It could be that organisations are becoming more aware of the polygamous nature of consumers and the low switching barriers for consumers (Beerli, Martin \& Quintana 2002; Kim, Shi \& Srinivasan 2001; Wendlandt \& Schrader 2007). Other reasons could include barriers to entry for firms such as high implementation costs of loyalty programs, difficulties surrounding how to build a strong membership base or how to introduce a program with unique offers from a late mover disadvantaged (Barnard 2010; Dowling \& Uncles 1997; Rowley 2005; Wendlandt \& Schrader 2007). The second highest ranking reason for non-membership was that the respondents did not find the benefits worth the effort. Previous research shows that value for money is still one of the most important factors which secure consumer buy-in (Barnard 2010).

Out of the 267 responses regarding drivers of participation in loyalty programs, the majority of respondents identified quality as the main factor that promotes loyalty. This is consistent with researchers such as Rowley (2005) who found that the quality of a product or service can have either a positive or a negative effect on the consumer's acceptance 
of loyalty programs. Although price was expected to be the number one loyalty promoting factor, it received the second highest score after quality. An important consumer characteristic that can possibly explain this phenomenon is that some consumers are willing to pay a premium for a product or service should it be of high level of quality (Beneke, 2010).

The majority of respondents gave the purpose of loyalty programs as "to reward frequent shoppers". From the literature it is clear that the main reasons behind the implementation of loyalty programs is the retention of customers (Bolton, Kannan \& Bramlett 2000; Lewis 2004; Gee, Coates \& Nicholson 2008). The second highest ranking purpose according to this study was "to ensure that customers return to the store" which is the intention of organisations when they use loyalty programs (Ghodeswar 2008; Kivets \& Simonson 2002).

In conclusion, research indicates that difficult economic circumstances are placing pressure on organisations to attract new customers and to retain their current customers. Customer relationship management has subsequently been brought to the fore as a strategic imperative by which to design strategies that are focussed on building customer relationships. One such a strategy is the implementation of loyalty programs whereby consumers are rewarded for their loyalty and return patronage to an organisation. It is evident that the respondents' perceptions of loyalty programs are in line with the intent identified in the literature in terms of the focus on rewarding frequent shoppers and ensuring repeat patronage. The study findings were therefore in alignment with the literature. A major weakness of this paper is the way the sample was selected. Sample selection started with an initial sample of 430 people whose contact details were on one of the researcher's contact list. The initial sample members were encouraged to distribute the questionnaire to their contacts to create a snowball effect. Using this approach, it was not possible to acquire a sample which is truly representative of an entire country. This presents an opportunity for future studies to undertake studies based on truly representative samples whose findings would be more generalizable.

\section{References}

Ailawadi, K.L. (2001). The retail power-performance conundrum: what have we learned? Journal of Retailing, 77(3), 299-318.

Anisimova, T. A. (2007). The effects of corporate brand attributes on attitudinal and behavioural consumer loyalty. Journal of Consumer Marketing, 24(7), 395-405. doi:10.1108/07363760710834816

Baltas, G., \& Argouslidis, P. C. (2007). Consumer characteristics and demand for store brands. International Journal of Retail \& Distribution Management, 35(5), 328-341. doi:10.1108/09590550710743708

Barnard, C. (2010). Reward \& Loyalty Programmes (SICCODE : 81920d) Retrieved Jun 20, 2012 (Available from the Who Owns Whom Essential Business Information Web site: http://www.whoownswhom.co.za/public/sasector/report_content/Pages\%20from \%2081920d\%20-\%20Reward\%20\&\%20Loyalty\%20Programmes\%20-\%20February\%202010\%20-\%20Contents.pdf)

Beerli, A., Martín, J. D., \& Quintana, A. (2004). A model of customer loyalty in the retail banking market. European Journal of Marketing, 38(1), 253-275. doi:10.1108/03090560410511221

Bendapudi, N., \& Berry, L. L. (1997). Customers' motivations for maintaining relationships with service providers. Journal of Retailing, 73(1), 15-37.

Beneke, J. (2010). Consumer perceptions of private label brands within the retail grocery sector of South Africa. African Journal of Business Management, 4(2), 203-220.

Bolton, R. N., Kannan, P. K., \& Bramlett, M. D. (2000). Implications of loyalty program membership and service experiences for customer retention and value. Journal of the Academy of Marketing Science, 28(1), 95-108. doi:10.1177/0092070300281009

Chauduri, A., \& Holbrook, M. B. (2001). The chain of effects from brand trust and brand affect to brand performance: The role of brand loyalty. Journal of Marketing, 65(2), 81-93.

Corstjens, M., \& Lal, R. (2000). Building store loyalty through store brands. Journal of Marketing Research, 37(3), $281-291$.

Demoulin, N. T. M., \& Zidda, P. (2009). Drivers of customers' adoption and adoption timing of a new loyalty card in the grocery retail market, Journal of Retailing, 85(3-2009), 391-405. doi:10.1016/j.jretai.2009.05.007

Dick, A. S., \& Basu, K. (1994) Customer loyalty: Toward an integrated conceptual framework. Journal of the Academy of Marketing Science, 22(2), 99-113.

Dowling, G. R., \& Uncles, M. (1997). Do customer rewards programs really work? Sloan Management Review, 38(4), 71-83.

Gee, R., Coates, G., \& Nicholson, M. (2008). Understanding and profitably managing customer loyalty. Marketing Intelligence \& Planning, 26(4), 359-374. doi:10.1108/02634500810879278

Ghodeswar, B. M. (2008). Building brand identity in competitive markets: A conceptual model. Journal of Product \& Brand Management, 17(1), 4-12. doi:10.1108/10610420810856468

Gruen, T. W. (1994). Exploring consumer behaviour with respect to memberships. Asia Pacific Advances in Consumer Research, 1 , 265-272.

Jensen, J. M. (2011). Consumer loyalty on the grocery product market: an empirical application of Dick and Basu's framework. Journal of Consumer Marketing, 28(5), 333-343. doi:10.1108/07363761111149983

Keh, H., \& Lee, Y. (2006). Do reward programs build loyalty for services? The moderating effect of satisfaction on type and timing of rewards. Journal of Retailing, 82(2), 127-136. doi:10.1016/j.jretai.2006.02.004

Kim, B., Shi, M., \& Srinivasan, K. (2001). Reward programs and tacit collusion. Marketing Science, 20(2), 99-120. 
Kivetz, R., \& Simonsom, I. (2002). Earning the right to indulge: Effort as a determinant of customer preferences toward frequency program rewards. Journal of Marketing Research, 39(2), 155-170.

Knox, S. D., \& Denison, T. J. (2000). Store loyalty: Its impact on retail revenue. An empirical study of purchasing behaviour in the UK. Journal of Retailing and Consumer Services, 7(1), 33-45.

Kumar, V., \& Shah, D. (2004). Building and sustaining profitable customer loyalty for the 21st century. Journal of Retailing, 80(4), 317330. doi:10.1016/j.jretai.2004.10.007

Leenheer, J., van Heerde, H. J., Bijmolt, T. H. A., \& Smidts, A. (2007). Do loyalty programs really enhance behavioural loyalty? An empirical analysis accounting for self-selecting members. International Journal of Research in Marketing, 24(1), 31-47. doi:10.1016/j.jijesmar.2006.10.005

Liu, Y. (2007). The long-term impact of loyalty programs on consumer purchase behaviour and loyalty. Journal of Marketing, 71(October), 19-35.

Liu, C., Guo, Y. M., \& Lee, C. (2011). The effects of relationship quality and switching barriers on customer loyalty. International Journal of Information Management, 31(1), 71-79. doi:10.1016/j.ijinfomgt.2010.05.008

Mägi, A. W. (2003). Share of wallet in retailing: The effects of customer satisfaction, loyalty cards and shopper characteristics, Journal of Retailing, 79(2), 97-106. doi:10.1016/S0022-4359(03)00008-3

Meyer-Waarden, L. (2008). The influence of loyalty programme membership on customer purchase behaviour. European Journal of Marketing, 42(1), 87-114. doi:10.1108/03090560810840925

Meyer-Waarden, L., \& Benavent, C. (2008). Grocery retail loyalty program effects: Self-selection or purchase behaviour change? Journal of the Academy of Marketing Science, 37(3), 345-358. doi:10.1007/s11747-008-0123-z

Oliver, R. L. (1999). Whence consumer loyalty? Journal of Marketing, 63(Special Issue), 33-44.

Pechtl, H. (2008). Price knowledge structures relating to grocery products. Journal of Product \& Brand Management, 17(7), 485-496. doi:10.1108/10610420810916380

Pepe, M. S., Abratt, R., \& Dion, P. (2011). The impact of private label brands on customer loyalty and product category profitability. Journal of Product \& Brand Management, 20(1), 27-36. doi:10.1108/10610421111107996

Perreault, W.D., Cannon, J.P. and McCarthy, E.J. (2010) Essentials of Marketing: A Marketing Strategy Planning Approach (twelfth edition), New York: McGraw-Hill//rwin

Prasad, C. J. S., \& Aryasri, A. R. (2008). Study of customer relationship marketing practices in organised retailing in food and grocery sector in India: An empirical analysis. The Journal of Business Perspective, 12(4), 33-43. doi:10.1177/097226290801200404

Radder, L., \& Huang, W. (2008). High-involvement and low-involvement products: A comparison of brand awareness among students at a South African university. Journal of Fashion Marketing and Management, 12(2), 232-243. doi:10.1108/13612020810874908

Rothschild, M. L., \& Gaidis, C. (2012). Behavioural learning theory: Its relevance to marketing and promotions. Journal of Marketing, 45(2), 70-78.

Rowley, J. (2005). Retailing and shopping on the Internet. International Journal of Retail \& Distribution Management, 24(3), 26-37.

Rowley, J. (2005). Building brand webs. Customer relationship management through the Tesco Clubcard loyalty scheme. International Journal of Retail and Distribution Management, 33(3), 194-206. doi:10.1108/09590550510588361

Sands, S., \& Ferraro, C. (2010). Retailers' strategic responses to economic downturn: insights from down under. International Journal of Retail \& Distribution Management, 38(8), 567-577. doi:10.1108/09590551011057408

Schoenbachler, D. D., Gordon, G. L., Foley, D., \& Spellman, L. (1997). Understanding consumer database marketing. Journal of Consumer Marketing, 14(1), 5-19.

Sharp, B., \& Sharp, A. (1997). Marketing loyalty programs and their impact on repeat-purchase loyalty patterns. International Journal of Research in Marketing, 14, 473-486.

Solanki, V.S., (2011). Implementation of e-CRM (Customer Relationship Management) in banking. Management Today, 1(1), $29-42$.

Srinivasan, R., Rangaswamy, A., \& Lilien, G. L. (2005). Turning adversity into advantage: Does proactive marketing during a recession pay off? International Journal of Research in Marketing, 22(2), 109-125. doi:10.1016/j.ijresmar.2004.05.002

Taylor, G. A., \& Neslin, S. A. (2005). The current and future sales impact of a retail frequency reward program. Journal of Retailing, 81(4), 293-305. doi:10.1016/j.jretai.2004.11.004

Uncles, M. D., Dowling, G. R., \& Hammond, K. (2003). Customer loyalty and customer loyalty programs. Journal of Consumer Marketing, 20(4), 294-316. doi:10.1108/07363760310483676

Wallace, D. W., Giese, J. L., \& Johnson, J. L. (2004). Customer retailer loyalty in the context of multiple channel strategies, Journal of Retailing, 80(4), 249-263. doi:10.1016/j.jretai.2004.10.002

Wendlandt, M., \& Schrader, U. (2007). Consumer reactance against loyalty programs. Journal of Consumer Marketing, 24(5), $293-304$. doi:10.1108/07363760710773111

Wirtz, J., Mattila, A. S., \& Lwin, M. O. (2007). How effective are loyalty reward programs in driving share of wallet? Journal of Service Research, 9(4), 327-334. doi:10.1177/1094670506295853

Yi, Y. \& Yeon, H. (2003). Effects of loyalty programs on value perception, program loyalty, and brand loyalty. Journal of the Academy of Marketing Science, 31(3), 229-240. doi:10.1177/0092070303253082 